\title{
SEGMENTING HUNGARIAN PEOPLE BASED ON HEALTHY EATING
}

\author{
Veronika Keller \\ Széchenyi University, Kautz Gyula Faculty of Businessand Economics, 9026 Győr, Egyetem tér 1.
}

kellerv@sze.hu

\begin{abstract}
Relying on customer trends healthy eating, which is one aspect of healthy lifestyle is becoming more and more popular. The aim of this study was to understand the healthy eating style of Hungarian adult consumers. An online empirical research with a sample of 1563 respondents (58.7\% females and $41.3 \%$ males) was conducted in November 2018. Considering healthy eating two factors, namely the choice of healthy foods and the avoidance of unhealthy foods could be distinguished. A hierarchical cluster analysis was conducted to segment consumers. Four groups of consumers were identified: unhealthy food avoiders (20.3\%), rejecters (11.8\%), neutrals (26.2\%) and healthy food choosers (14.7\%). Unhealthy food avoiders are seniors. Rejecters are blue collar workers and have financial problems. Healthy food choosers live in families with children over 10 and do not have weight problems. This study is useful for the health sector and the government since targeted marketing programs can be planned to change eating behavior. To decrease overweight and obesity is the goal of all society, especially in developed countries. To increase the well-being of people and their quality of life educating social marketing campaigns are necessary with the aim of raising their awareness and explaining the basic principles of a healthy diet.
\end{abstract}

Keywords: healthy eating, perception, segmentation

(JEL Classification: 112, M30, M39)

\section{INTRODUCTION}

Researchers (törőcsik, 2014) identified the 'extension of health market', as one of the major trend in the 21st century. Households spend higher and higher amount of money the prevention and development of health and healing in case of illnesses. Dudás (2011) identified the elements of conscious consumer behavior and health consciousness is one aspect of that which means an approach, or a behavior and an activity to be healthier in the long run. One element of health consciousness is healthy and moderate food intake. Considering the most up-to-date food trends it can be said that plant based diet is becoming more and more popular. Previously meat was an important source of nutrient but nowadays there are a lot of skepticism about it such as healthiness, environmental and sustainability issues. There is a great demand for local fresh fruit and vegetable since vegetables become the main dishes. Vegetable symbolizes freshness, innocence and health (trendinspiracio.Hu/aktualistrendek-2019/). Health and healthy eating is an important topic for people. Relying on the most up-to-date researches of gfk hungary research institute (2019) hungarian consumers put more emphasis on the healthiness of food products. People eat regularly especially older people however younger people do not pay attention to eat regularly. Most of the hungarians eat three times a day and breakfast and lunch are the most important occasions of eating. When they purchase food products four aspects are the most important: taste, healthiness, ingredients and previous positive experiences (gfk research institute, 2019).

Considering the eating behavior of hungarian people the results of the hungarian diet and nutritional status survey (otáp - országos táplálkozás és tápláltsági állapot vizsgálat, 2014) can show a good overlook (nagy et al. 2017). The results of the latest survey show that hungarian adults are not so healthy. Mainly females had increased their fat intake especially their saturated fat intake. The fiber intake had shown a decreasing and added sugar intake had shown an increasing tendency. The vitamin intake was inappropriate of adults and the population could decrease their salt-intake but it 
was still above the norm by 2.5 Times. Considering fruit and vegetable (without potato) consumption females (346 g/day) were in a better situation than males ( $330 \mathrm{~g} / \mathrm{day}$ ) but it was still below the suggested level $(400 \mathrm{~g} / \mathrm{day})$. Cereals $(86.3 \mathrm{Kg} / \mathrm{capita} /$ year) fruit and vegetable together with potato $(81.8 \mathrm{Kg} / \mathrm{capita} /$ year) were the most important sources of food intake in 2017. People consumed more pastry (bakery products with white meal) and flavored cereals and sweeteners (egészségjelentés, 2017; ksh, 2018)

The inappropriate eating habits are responsible for overweight and obesity which are considered to be the world's epidemic. Relying on the most up-to-date statistics of world health organization (who) in 2017 the average body mass index (bmi) of hungarian adult population was $27.52 \mathrm{Kg} /$ $\mathrm{m} 2$, which was a little bit lower among females $(26.65 \mathrm{Kg} /$ m2) than among males $(28.39 \mathrm{Kg} / \mathrm{m} 2) .30 \%$ of the total population is obese. According to ncd risc living in rural preas have a higher level of average bmi than people living areas have a higher level of average bmi than people living in cities. Relying on the health survey of ksh (central statistical office) from 2014 , more than half of the entire hungarian
population $(54 \%)$ was overweight $(25 \leq \mathrm{bmi}<30$ ) or obese $(\mathrm{bmi}>30)$. This rate was higher in case of men $(62 \%)$ than in case of women (49\%). Based on age it can be said that $23 \%$ of young females were overweight or obese and $39 \%$ of young males. As people are getting older their bmi is increasing, too. $53 \%$ Of middle aged females and $71 \%$ of middle aged males had problems with their weight. Among older people weight problems were even more common, $65 \%$ of elderly women and $72 \%$ of elderly men suffered from overweight and obesity (european health interview survey, 2014).

In this paper the healthy eating style of hungarian people is analyzed from a marketing viewpoint. After the theoretical background the result of an empirical quantitative study is presented.

\section{MATERIALS AND METHODS}

Perception of healthy eating can be defined as 'the public's and health professionals' understandings, views, attitudes and beliefs about healthy eating and healthy foods (Paquette, 2005: 15). Taking into consideration healthy eating or healthy diet the WHO principles are the following:

Fruit, vegetables, legumes, nuts and whole grains should be the most important sources of nutrients. At least $400 \mathrm{~g}$ (i.e. five portions) of fruit and vegetables per day should be consumed.

Less than $10 \%$ of total energy intake should come from free sugars.

Less than $30 \%$ of total energy intake should come from fats. Unsaturated fats are preferable to saturated fats. It is suggested that the intake of saturated fats be reduced
to less than $10 \%$ of total energy intake and trans-fats to loss than $1 \%$ of total energy intake. In particular, inless than $1 \%$ of total energy intake. In particular, in-
dustrially-produced trans-fats are not part of a healthy dustrially-produced trans-fat
diet and should be avoided.

diet and should be avoided.
Less than $5 \mathrm{~g}$ of salt per day should be consumed (who.

int/news-room/fact-sheets/detail/healthy-diet).
More authors (Paquette, 2005 and Lake et al. 2007) found hat healthy eating influence food intake. Fruits and vegetables are important elements of healthy eating. Naturalness, fat, sugar and salt contents are other important aspects of healthy eating perception. Dutta-Bergman (2004) developed a scale containing 11 items to measure healthy eating one aspect of health consciousness. The scale contains attitude statements related to intention to eat nutritious foods with vitamins, calcium, fiber and avoid unhealthy foods with high cholesterol, fat, salt and sugar content.

More international researches focused on segmenting eople based on their healthy or unhealthy eating behavio André et al. 2017; Heerman et al. 2017, Psouni et al. 2016; LV et al., 2011). Some papers concentrated on children (Sabbe et al 2008) or adolescents (Cuenca-García et al. 2013, MATIAS et al. 2018) and clustered youths based on eating behavio and physical activity or sedentary behavior. These studies anlyzed the demographics of each group and found gender differences. WAH (2016) and LV et al. (2011) also gender behavior of food and oily food with carbohydrate. Femoles care, junk bout their body weight and eas less and ent more fruit an (WAH 2016). GRACA less and eat more fruit an geta (WAH, 2016). GRACA et al. (2015) highighted that eat was more important for males and females were willin apt a more plant-based diet to be healthier.

Among international researches more empirical result could be found that investigated a special consumer grou (Tanton et al. 2015; André et al. 2017; Benedet et al. 2017). Tanton et al. (2015) analyzed the eating behavior of British university students whose lifestyle is considered to be risky when it comes about eating. The researchers used the consumption of snacks, convenience, and fast foods an fruit and vegetable. They identified four segments: risky, mixed, moderate and favorable eating behavior. The majority of university students had an unfavorable eating behavior Anrdé et al. (2017) categorized senior Norwegian citizen $(65+)$ based on similarities of food consumption. They distinguished people with unhealthy food pattern (21.5\%) an people with healthy food pattern (78.5\%). The first group of people consumed a larger amount of food and beverages such as chocolate/candy, pasta, sausages, sugar free and sugary soft drinks, whole milk, juice, white bread and semi-grain bread. The second group of people consumed more fruit, vegetable, boiled potato, oily fish, whole-grain bre fruit, verer. wath fod habits (low int of

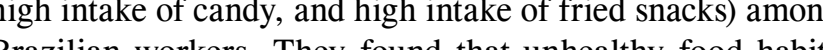
(ith food habits were nore frequent anong with a lowe end his co-au, an (2017) ide ified eating styles froma and his co-authors (2017) identified eating styles from six eating behaviors (rrequency of eating healthy food, frequency of eating unheal hy food, breakfast frequency, frequency of snacking, overall diet quality and problen eating behaviors and tested their association with BMI among adults. Four eating styles were identified and defined by healthy vs. unhealthy diet patterns and engagement in problem eating behaviors. Unhealthy and unhealthy problem eating group had significantly higher BMI than healthy eaters. Psouni et a (2016) investigated the patterns of eating and physical activity attitudes and behaviors in relation to BMI. They also identified healthy and unhealthy group of Greek people. Healthy people were related to healthier exercise and eating behavior. They had normal BMI. Unhealthy people were related to lowe level of exercise and healthy eating. They belonged to the overweight category considering their BM

The relevance of this topic can be explained by an initiation of SZONDA IPSOS in 2007. The research institute investigated the Hungarian population based on health styles (smoking, alcohol consumption, physical activity, nutrition and control weight) in a longitudinal study. A similar research was conducted in Netherland (Vries et al. 2008). They identified clusters based on five important preventive health behaviors, nasters based mone

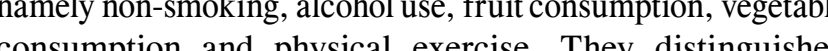
consumption and physical exercise. They distinguished

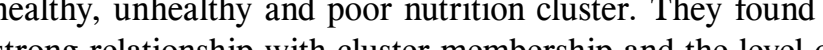
che level of was. LV and hisco-are was. LV and his co-auts (and 18 and 64). They id survey among Chinese adrs (aged 18 and 64). They identified (25.7\%), (25.7\%), a moderately healthy (31.1\%) and a healthy $(43.1 \%)$ group. Tobacco use, physical activity, fruit and vegetable consumption and out-of-home eating were analyzed among lifestyle variables. Men were more likely than women to have unhealthy lifestyles. Adults aged 50 and 64 were more likely to live healthy lifestyles. Adult aged 40 and 49 were more likely to follow an unhealthy lifestyle. They also highlighted the relationship with cluster membership and the level of education and asset index

The aim this research was to explore the perception of healthy eating in Hungary there are some educationa initiatives and programs by health government, and public education connected to eating behavior (school lunch reform and school fruit program) and physical activity (obligatory PE lessons every day). At the same time the attitude an behavior of Hungarian people have been changing slowly and there is a major gap between the recommendation and actual eating habits.

Based on the literature review the following marketing research problem has aroused: to identify the components of healthy eating and to identify homogenous consumer groups based on the results of factor analysis, and characterize them based on demographics. The main research questions were the following:

a) What kind of factors can be distinguished based on healthy eating?

b) Is it possible to segment consumers based on healthy eating?

c) Is it possible to profile each segment based on demographic (gender, age, family lifecycle, residence, occupation, income vel, and BMI)?

To answer the research questions three hypotheses were defined:

$\mathrm{H}_{\mathrm{a}}$ : Different factors can be distinguished based on healthy eating.

$\mathrm{H}_{\mathrm{b}}$ : Consumers can be grouped into homogeneous groups based on healthy eating.

$\mathrm{H}_{\mathrm{c}}$ : It is possible to profile each segment based on demographics (gender, age, family lifecycle, residence, occupation, income level, and BMI).

Measurement and specification of scales

The method of primary research was the survey method. In the questionnaire we mainly used metric scales, but we made scales.

Examining healthy eating the scale developed by Dutta-Bergman (2004) was used. Response categories ranged from 1 'totally disagree' and 5 'totally agree'.

The scale contained 11 items. The following attitude statements were included in the questionnaire:

1. I try to avoid foods that are high in fat.

2. try to avoid foods that are high in cholesterol.

3. Nutrition information determines what I buy.

4. I make a special effort to get enough fiber.

5. I am concerned about how much sugar 1 eat

. I try to avoid foods with a high salt content

I try to select food fortified with vita
I use a lot of low calorie products.

8. I use a lot of low calorie products.
9. I try to avoid foods with high additives.

9. I try to avoid foods with high additives.
10. I am careful what I eat to keep weight in control.

11. I am concerned about getting enough calcium.

Gender was measured on nominal scale.

Age was measured on ratio scale and we recoded into nominal scale to categorize respondents into three categories, youths (18-34), middle-aged (35-50) and seniors $(51+)$.

The other demographic variables were measured on nonmetric, categorical scales.

Sample design and data analysis

To answer the research questions the author chose single cross-sectional research method. The authors used the quota sampling design. A proportional sampling technique based on gender was chosen. Originally the researcher planned to question the same number of people in each gender group, which meant $50 \%$ of males and $50 \%$ of females. The planned size of the sample was 1000 respondents.

The empirical research was conducted in November 2018. To obtain the primary information, the online questionnaire was sent to different social media groups. Finally 1563 people could be reached with the survey and were willing to fulfil the whole questionnaire. Actually the researcher could not maintain the planned sample design. The ratio of males to females is $41.3 \%$ to $58.7 \%$. Based on age three generations were investigated: $60.9 \%$ youths (18-34 years), $25.3 \%$ middle-aged
(35-50 years) and $13.8 \%$ senior people (above 51 years). The 
sample can be characterized with the following demographics and health state characteristics (Table 1).

Table 1: Basic demographics of the sample

\begin{tabular}{|c|c|c|c|c|}
\hline Residence: & $\begin{array}{l}\text { villages } \\
33.7 \%\end{array}$ & $\begin{array}{l}\text { towns } \\
20.5 \%\end{array}$ & $\begin{array}{c}\text { cities } \\
34.6 \%\end{array}$ & $\begin{array}{c}\text { capital city } \\
6.9 \%\end{array}$ \\
\hline \multirow{2}{*}{ Occupation: } & $\begin{array}{c}\text { white collar } \\
\text { workers } \\
34.9 \%\end{array}$ & $\begin{array}{c}\text { blue collar } \\
\text { workers } \\
23.3 \%\end{array}$ & $\begin{array}{l}\text { students } \\
30.3 \%\end{array}$ & $\begin{array}{c}\text { unemployed } \\
1.6 \%\end{array}$ \\
\hline & $\begin{array}{c}\text { dependents } \\
2.3 \%\end{array}$ & $\begin{array}{l}\text { retired } \\
5.0 \%\end{array}$ & $\begin{array}{l}\text { other } \\
3.0 \%\end{array}$ & $\begin{array}{ll}- & \text { r }\end{array}$ \\
\hline $\begin{array}{c}\text { Family } \\
\text { lifecycle: }\end{array}$ & $\begin{array}{c}\text { single } \\
36.5 \%\end{array}$ & $\begin{array}{c}\text { lived in } \\
\text { relation- } \\
\text { ship without } \\
\text { children } \\
31.8 \%\end{array}$ & $\begin{array}{c}\text { lived in } \\
\text { relationship } \\
\text { with children } \\
\text { under } 10 \\
15.0 \%\end{array}$ & $\begin{array}{c}\text { lived in } \\
\text { relationship } \\
\text { with children } \\
\text { over } 10 \\
16.8 \%\end{array}$ \\
\hline \multirow{2}{*}{$\begin{array}{l}\text { Income } \\
\text { level: }\end{array}$} & $\begin{array}{c}\text { financial } \\
\text { problems } \\
8.6 \%\end{array}$ & $\begin{array}{c}\text { low income } \\
13.0 \%\end{array}$ & $\begin{array}{c}\text { do not com- } \\
\text { plain } \\
40.4 \%\end{array}$ & $\begin{array}{c}\text { can save } \\
\text { money } \\
21.3 \% \\
\end{array}$ \\
\hline & $\begin{array}{c}\text { live in } \\
\text { financial } \\
\text { prosperity } \\
14.5 \%\end{array}$ & - & $\begin{array}{ll}- & \text { - }\end{array}$ & - \\
\hline $\begin{array}{l}\text { BMI cat- } \\
\text { egory: }\end{array}$ & $\begin{array}{c}\text { underweight } \\
5.9 \%\end{array}$ & $\begin{array}{l}\text { normal } \\
\text { weight } \\
50.9 \%\end{array}$ & $\begin{array}{c}\text { overweight } \\
\text { (less than } 10 \\
\text { kg plus) } \\
31.7 \%\end{array}$ & $\begin{array}{c}\text { obese (more } \\
\text { than } 10 \mathrm{~kg} \\
\text { plus) } \\
11.4 \%\end{array}$ \\
\hline
\end{tabular}

\section{Source: Own research}

The sample was not a representative one the authors would like to emphasize this study is an exploratory one and the main conclusions are true for this sample only.

The data analysis was conducted with the help of SPSS 23.0 software. To answer the research questions multivariate statistical analysis was conducted. To answer the first research question the authors used factor analysis. The method of factor extraction was the principle component analysis. The number of factors was determined by the priori determination (3) and approaches based on the eigenvalues (5), the scree plot (5) and the percentage of variance accounted for (5). The number of factors was determined by the eigenvalues. The benchmark of factor loading above 0.4 was applied as a criterion for item inclusion in each factor (TSOGAS et al. 2010: 4.). The rotation of factors was assessed by the method of Varimax. To answer the second research question the method of cluster analysis, especially the method of Ward's hierarchical cluster analysis, namely the agglomerative clustering was used (Malhotra, 2018). Since the aim was to emphasize the main differences square Euclidean distance was used to measure the distances. After investigating the pre-conditions, the researchers considered different cluster solutions, but finally they decided to apply the three cluster solution. In ve next step they considered these three clusters as nominal variables. In order to answer the third research question to analyze the connection between cluster membership and basic demographics Chi-square analysis was conducted. In this case the authors took into consideration the expected value and condition of variables measured on nominal scales.

\section{ESULTS AND DISCUSSION}

Healthy eating

In connection with healthy eating 11 statements were examined. In this case the value of Cronbach $\square$ was 0.921 , whic means that this scale is consistent. The values of indicator proving the appropriateness of factor analysis were appropriate (KMO: 0.921, Bartlett's Test: 6586.563, Sig. 0.000). The number of factors was determined by Scree-test that is two factors could be distinguished that explained $63.173 \%$ of the total variance.

The first factor contained five variables which represented conscious behavior and the choice of nutritious foods that are good for the body:

I try to select food fortified with vitamins. 0.828 I make a special effort to get enough fiber $\quad 0.801$ $\begin{array}{ll}\text { I try to avoid foods with high additives. } & 0.801 \\ & 0.760\end{array}$

I am concerned about getting enough calcium. 0.758

I am concerned about how much sugar I eat. 0.758

The total variace explain by this fartor was $31.723 \%$ The total variance explained by this factor was $31.723 \%$ The value of Cros 0.867

be variables which represented fusal of unhealthy foods which are harmful for the body:

I try to avoid foods that are high in cholesterol. 0.832

I use a lot of low calorie products. $\quad 0.806$

I try to avoid foods that are high in fat. $\quad 0.726$

I try to avoid foods with a high salt content. $\quad 0.686$

Nutrition information determines what I buy. 0.55

- I am careful what I eat to keep weight in control.0.55

The total variance explained by this factor was $31.450 \%$ an the value of Cronbach $\square$ was 0.863. It can be stated that differen factors can be distinguished based on healthy eating, namely the choice of nutritious food and the refusal of unhealthy foods.

Consumer groups based on healthy eating

In the next step using the results of factor analysis were used for clustering. Relying on the results of Elbow criterion and Agglomeration schedule the four cluster solution was chosen. Count and frequency in case of each cluster was the following: 1st cluster 317 people $(20.3 \%$ ), 2nd cluster 185 people $(11.8 \%$ ) the 3 rd cluster 409 people (26.2\%) and 230 people (14.7\%). In order to make a typology for the different clusters analysis of the means was necessary. The method of one way ANOVA was used The was althy foods - CHF, refus of f 0.000 . 20.0.472. FRUF: $748.369, \mathrm{p}: 0.000,02 \cdot 0.568$ ). There $0.000,02.0 .472$, FRU : $48.369, \mathrm{p}: 0.000,02.0 .568)$. There were To test the hor in we T3 test he homogenenty of valiales Post-Hoc tests (Dunnett 13 and LSD) were conducted. Relying on the results there wer statistically significant differences among variables.

why and toed avoiders (20.3\%). they try to eat in a healthy way and they typically refuse unhealthy foods such as food with high cholesterol value, fat and salt content. They prefer low calorie foods and make their purchasing decision based on nutrition. They pay attention on their weight.

2. Rejecters (11.8\%): they could not be characterized by choice of healthy foods or refusal of unhealthy foods. They have a negative attitude towards the aspects of healthy eating.

3. Neutrals (26.2\%): are neutral when it comes about healthy eating.

4. Healthy food choosers (14.7\%): could be characterized by the choice of healthy foods. They put an emphasis on eating foods with vitamin, fiber, calcium (Table 2).

Table 2: Results of cluster analysis

\begin{tabular}{|c|c|c|c|}
\hline \multicolumn{2}{|c|}{$\begin{array}{l}\text { Hierarchical cluster analysis } 4 \text { cluster } \\
\text { solution }\end{array}$} & \multirow{2}{*}{$\begin{array}{c}\begin{array}{c}\text { Choice of } \\
\text { healthy foods }\end{array} \\
0.063\end{array}$} & \multirow{2}{*}{$\begin{array}{c}\begin{array}{c}\text { Refusal of } \\
\text { unhealthy } \\
\text { foods }\end{array} \\
1.191\end{array}$} \\
\hline \multirow{3}{*}{$\begin{array}{l}\text { Cluster 1: Un- } \\
\text { healthy food avoid- } \\
\text { ers; } 20.3 \%\end{array}$} & Mean & & \\
\hline & $\mathrm{N}$ & 317 & 317 \\
\hline & Standard deviation & 0.777 & 0.471 \\
\hline \multirow{3}{*}{$\begin{array}{l}\text { Cluster 2: Reject- } \\
\quad \text { ers; } 11.8 \%\end{array}$} & Mean & -1.506 & -0.558 \\
\hline & $\mathrm{N}$ & 185 & 185 \\
\hline & Standard deviation & 0.361 & 0.618 \\
\hline \multirow{3}{*}{$\begin{array}{l}\text { Cluster 3: Neutrals; } \\
\text { 26.2\% }\end{array}$} & Mean & 0.269 & 0.0454 \\
\hline & $\mathrm{N}$ & 409 & 409 \\
\hline & Standard deviation & 0.644 & 0.402 \\
\hline \multirow{3}{*}{$\begin{array}{l}\text { Cluster 4: Healthy } \\
\text { food choosers; } \\
14.7 \%\end{array}$} & Mean & 0.644 & -1.274 \\
\hline & $\mathrm{N}$ & 230 & 230 \\
\hline & Standard deviation & 0.955 & 0.471 \\
\hline \multirow{3}{*}{ Count } & Mean & 0.000 & 0.000 \\
\hline & $\mathrm{N}$ & 1141 & 1141 \\
\hline & Standard deviation & 1.000 & 1.000 \\
\hline
\end{tabular}

Source: $O$ wn research, $n=1140$ respondents

It can be stated that consumers can be grouped into homogeneous groups based on healthy eating factors (choice of healthy foods, refusal of unhealthy foods). Four groups of consumers were identified: unhealthy food avoiders (20.3\%), rejecters $(11.8 \%)$, neutrals $(26.2 \%)$ and healthy food choosers $(14.7 \%)$

Profiling consumer groups

In order to analyze the connection between cluster membership and basic demographics cross tabulation (Chisquare analysis) was conducted. The relationship with cluster membership and gender, generation, occupation, family lifecycle, income level, and BMI were analyzed. Significan relationships incase of generation $\left(\chi^{2}=15.944 ; \mathrm{p}=0.01\right)$, residence $\left(x^{2}=23.168 ; \mathrm{p}=0.02\right)$, occupation $\left(x^{2}=77.203 ; \mathrm{p}=0.00\right)$, famil lifecycle $\left(\chi^{2}=18.446 ; p=0.03\right)$, income level $\left(\chi^{2}=25.549\right.$ $\mathrm{p}=0.01)$ and BMI $\left(\chi^{2}=20.389 ; \mathrm{p}=0.01\right)$ were found. Howeve these connections were very weak (Cramer's $V_{\text {generation }}=0.08$;
Cramer's $V_{\text {residence }}=0.08$, Cramer's $V_{\text {occupation }}=0.15$, Cramer's $\mathrm{V}_{\text {family lifecycle }}$ residence
(Table 3).

Relying on the results of adjusted standardized residuals it can be stated that unhealthy food avoiders are seniors. Rejecters are blue collar workers and have financial problems. Healthy food choosers live in families with children over 10 and do not have weight problems (Table 3).

Table 3: Clusters and basic demographics

\begin{tabular}{|c|c|c|c|c|c|c|}
\hline \multirow{2}{*}{\multicolumn{2}{|c|}{ Demographics }} & \multicolumn{5}{|c|}{ Adjusted standardized residuum } \\
\hline & & \multirow{2}{*}{$\begin{array}{c}\begin{array}{c}\text { un- } \\
\text { healthy } \\
\text { food } \\
\text { avoiders }\end{array} \\
2.2 \\
2.2\end{array}$} & \multirow{2}{*}{\begin{tabular}{c|} 
rejecters \\
$-1,5$
\end{tabular}} & \multirow{2}{*}{$\begin{array}{c}\text { neutrals } \\
0.5\end{array}$} & \multirow{2}{*}{\begin{tabular}{|c|}
$\begin{array}{c}\text { healthy } \\
\text { food } \\
\text { choosers }\end{array}$ \\
-2.0 \\
\end{tabular}} & \multirow{2}{*}{\begin{tabular}{|c}
$\begin{array}{c}\text { Sign } \\
\text { relation } \\
\text { with } \\
\text { clusters }\end{array}$ \\
$\begin{array}{c}\text { un- } \\
\text { healthy } \\
\text { food } \\
\text { avoider }\end{array}$
\end{tabular}} \\
\hline Age & senior & & & & & \\
\hline \multirow[b]{2}{*}{$\begin{array}{c}\text { Occupa- } \\
\text { tion }\end{array}$} & $\begin{array}{l}\text { blue } \\
\text { collar }\end{array}$ & -0.6 & 3.5 & -0.6 & -1.5 & rejecter \\
\hline & other & -1.8 & -2.1 & -0.1 & 4.2 & $\begin{array}{l}\text { healthy } \\
\text { food } \\
\text { choosers }\end{array}$ \\
\hline $\begin{array}{l}\text { Family } \\
\text { lifecycle }\end{array}$ & \begin{tabular}{|l|} 
fam- \\
fily with \\
children \\
over 10 \\
\end{tabular} & -0.9 & -0.5 & -0.6 & 2.2 & $\begin{array}{l}\text { healthy } \\
\text { food } \\
\text { choosers. }\end{array}$ \\
\hline $\begin{array}{l}\text { Income } \\
\text { level }\end{array}$ & $\begin{array}{l}\text { financial } \\
\text { problems }\end{array}$ & -2.4 & 2.0 & -0.5 & 1.7 & rejecters \\
\hline BMI & normal & -0.2 & -1.2 & -0.8 & 2.4 & $\begin{array}{l}\text { healthy } \\
\text { food } \\
\text { choosers }\end{array}$ \\
\hline
\end{tabular}

Source: Own research

It is possible to profile each segment based on demographics, especially based on age, occupation, family lifecycle, income level and BMI. Unhealthy food avoiders are seniors. Rejecters are blue collar workers and have financial problems. Healthy have weight problems.

Discussion

More international studies focused on clustering adult population based on healthy eating or lifestyle. Benedet et al. (2017) concentrated on unhealthy food habits and Anrdé et al. categorized senior Norwegian citizens based on similarities of food consumption. This research focused on the healthy eating style of Hungarian adults. Considering healthy eating two factors were identified: choice of healthy foods and refusal of unhealthy foods. The first behavior was referring to eating healthy, nutritious foods and the second one meant avoiding junk foods. A hierarchical cluster analysis was conducted to segment consumers based on their healthy eating (choice of healthy foods, refusal of unhealthy foods). Four groups of consumers were identified: unhealthy food avoiders (20.3\%), rejecters (11.8\%), neutrals (26.2\%) and 
healthy food choosers $(14.7 \%)$. Unhealthy food avoiders try to eat in a healthy way and they typically refuse unhealthy foods such as foods with high cholesterol value, fat and salt content. They prefer low calorie foods and make their purchasing decision based on nutrition. They pay attention on their weight. Rejecters could not be characterized by choice of healthy foods or refusal of unhealthy foods. They have a negative attitude towards the aspects of healthy eating. Neutrals are neutral when it comes about healthy eating. Healthy food choosers could be characterized by the choice of healthy foods. They put an emphasis on eating foods with vitamin, fiber, calcium. In order to profile each segment cross tabulation was conducted. There were statistically significant relationships in case of generation, residence, occupation, family lifecycle, income level and BMI. Unhealthy food avoiders are seniors. Rejecters are blue collar workers and have financial problems. Healthy food choosers live in families with children over 10 and do not have weight problems. WAH (2016) and LV et al. (2011) highlighted gender differences that females are more health-conscious, they eat less and smaller proportions and take care of weight control. However there were no gender differences in this empirical research. More studies (Benedet et al. 2017, Vies et al. 2008, LV etal. 2011) emphasized the importance of education level in healthy lifestyle. However in this study the level of education was not investigated. found the healhy (Psonni et al. 2017, Heerman et al. 2017) did not suffer fry eaters had lower level of BMI and they present results since people with normal weight are healthy food choosers.

\section{CONCLUSIONS AND FURTHER RESEARCH}

Present study is useful for the health sector (doctors, dieticians and food experts) and the government since targeted marketing programs can be planned to change eating behavior. In case of government social marketing programs would be necessary. Raising the health consciousness of neutrals and rejecters (38\%) is also important. The barriers of healthy eating are the lack of support from others and knowledge, cooking skills, availability, willpower. Price (too expensive, preparation time and hedonics such as too boring, not tasty are also barriers to healthy eating (MARROW et al. 2016). In order to increase the quality of life and wellbeing of people it is necessary to improve their health. Health is not only the state of being free from illness or injury, but it is even a more complex category. A sound mind in a sound body should be emphasized in social marketing campaigns. To decrease overweight and obesity is the goal of all society (especially in developed countries where this phenomenon is considered to be an epidemic) that is why educating people and applying social marketing campaigns are necessary. Informing people about the correct eating habits and the principles of a balanced nutrition (food pyramid, WHO principles) should be communicated to people. Developing applications and smart equipment like smart plate, fork could help them to follow the basic principles of healthy eating. These applications could be eveloped with the cooperation of doctors, dietitians an nutrition consultancy. Educating people and changing their unhealthy habits is the interest of a society. Not only education but raising attention of people with emphasizing the consequences of bad eating habits should be in focus. The social marketing campaign aims to change people's attitudes and behavior. The behavior is driven by many factors and two factors - benefits and costs - are at the heart of the changing process. The non-profit manager seek to amplify benefits and reduce costs in order to get target publics to behave in certain ways such as eating healthy. Many times people have social support and belief in the beneficial effects of behavior such as stopping eating snacks, but are unable to adopt it because they think they actually cannot succeed.

Finally the limitation of present study should be Finally the linitation of present study should be highlighted. The most important limitation is the nona regiont anis Pann region and one third of the sample belong to the elf-dectarion self-ceclaration on healthy eating perceptions instead of Intely measured data (food diaries).

In the future the researcher would like to highlight other lifestyle differences. Another possible direction of this research is to analyze the consumption of differen food products and conducting a cluster analysis base on consumption patterns. Thus the actual behavior an healthy eating patterns could be compared. It is also worth 0 analyze the barriers of healthy eating. There are some stereotypes like price, boredom, not tasty, etc. when it comes about healthy eating. Since a major part of the population can be characterized by low involvement whe it comes about healthy eating their rejections and driver should be identified.

\section{ACKNOWLEDGMENTS}

The author is deeply grateful to respondents who fulfilled the questionnaire. This work was supported by Széchenyi István University and the Hungarian Government and the European Union within the European Structural and Investment Funds. This study was written as a part of a project entitled EFOP-3.6.1-16-2016-00017, "Internationalization, initiatives to establish a new source of researchers and graduates, and development of knowledge and technologica ransfer as instruments of intelligent specializations at Széchenyi University".

\section{REFERENCES}

André B., Canhão H., Espnes G. A., Rodrigues, A. M. F., Gregorio, M. J., Nguyen, C., Sousa, R., Grønning, K. (2017): Is there an
association between food patterns and life satisfaction among
Norway's inhabitants ages 65 years and older?, Appetite, $110(12)$ org/10.1016/j.appet.2016.12.016

Annual rate of consumption per capita based on income decile an regions and type of settlement (Az egy fốre jutó éves éelelmiszerfogyasztás mennyisége jövedelmi tizedek (decilisek), régiók és xstadat/xstadat eves/i zhc023b.html?down=8000 (Accessed: 15 2019)

Benedet J., Del Duca G. F., Silveira P. M., Coutinho A. P. P. Oliveira E. S. A., Nahas M. V. (2017): Clustering of unhealthy foo habits and its association with socioeconomic factors among Brazilia workers. Rev. Nati., Campinas, 30 (6). 795 - 804. Permanent

Cuenca-García M., Huybrechts I., Ruiz J. R., Ortega F. B.,
Ottevaere C. et al. (2013): Clustering of Multiple Lifestyle Behaviors and Health- related Fitness in European Adolescents. Journal of Nutrition Education and Behavior, Vol. 45 Iss 6 pp. 549
-557 Permanent link to this document: http://dx.doi.org/10.1016/j.

- 557 Permanent liak

Dudás, K. (2011): A tudatos fogyasztói magatartás dimenziói http://unipub.lib.uni-corvinus.hu/2621/1/vt2011n7-8p47-55.pdf

Dutta-Bergman M. J. (2004): Primary sources of health information: Comparisons in the domain of health attitudes, health cognitions,
and health behaviors, Health Communication, 16 (3): $273-288$ Permanent link to this document: DOI: 10.1207/S15327027HC1603 Egészségjelentés 2016 (2017). Nemzeti Egészségfejlesztési Intéze (http://www.egeszseg.hu/szakmai_oldalak/assets GfK: GfK Sajtóközlemény (2019.02.13) Ma már az, hogy mennyir egészséges, amit eszünk, csaknem annyira fontos, mint hogy ízletes

Graca J., Calheiro, M. M., Oliveira A. (2015): Attached to meat? (1): 113 - 125. Permanent link to this document: DOI: $10.1016 / \mathrm{j}$. (1): 113 - 125. Pet

Heerman W. J., Jackson N., Hargreaves M., Mulvaney S. A Schlundt D., Wallston K. A., Rothman R. L. (2017): Clusters of Healthy and Unhealthy Eating Behaviors Are Associated With Body Mass Index Among Adults, Journal of Nutrition Education an dx.doi org $/ 10.1016 /$ j jneb. 2017.02 .001

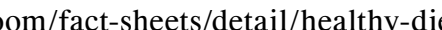
(Accessed: May 152019

KSH (2018): Egészségi állapot és egészségmagatartás, 2016-2017. Statisztikai Tükör, Budapest.

KSH (2018): European Health Interview Survey, 2014. A 2014Összefoglaló adatok: http://www.ksh.hu/docs/hun/xttp/idoszaki/ elef/elef2014_osszefoglalo.pdf, ISBN 978-963-235-508-5

Lake A. A., Hyland R. M., Rugg-Gunn A. J., Wood C. E., Mathers J. C., Adamson, A. J. (2007): Healthy eating: Perceptions an
practice (the ASH30 study), Appetite, 48 (2): 176 - 182. Permanen link to this document: https://doi.org/10.1016/j.appet.2006.08.065 Lv J., Liu Q., Ren Y., Gong T., Wang S., Li L. (2011): Socioand their clustering in a representative urban population of adults: a cross sectional study in Hangzou, China, International Journal of Behavioral Nutrition and Physical Activity, 8 (40): 1 - 13. Permanent link to this document: doi: $10.1186 / 1479-5868-8-40$. Malhotra N. K. (2018): Marketing Research. An applied orientation.
7th ed. New Jersey: Prentice Hall, 2010 ISBN-13: 978-0134734842 Marrow L. Mc., Ludbrook A., Macdiarmid J. I., Olajide D. (2016): fruit and vegetable consumption, Journal of Public Health, Vol. 39
Iss. 2 pp. 330 - 338 Permanent link to this document: doi: 10.1093/
pubmed/fdw 38 .

Matias T. S., Silva K. S., Aragoni da Silva J., Thais de Mello G., Salmon J. (2018): Clustering of diet, physical activity and sedentary behavior among Brazilian adolescents in the national school 1 - 9. Permanent link to this document: https://bmepublichealth. biomedcenthe Nagy B., Nagy-Lốrincz Zs., Bakacs M., Illés É., Sarkadi Nagy E., Martos É. (2017): Országos Táplálkozás és Tápláltsági Állapot Vizsgálat - OTÁP2014. III. A magyar lakosság makroelem-bevitele. Orv Hetilap, 158 (17): 653-661. Hungarian Diet and Nutritional
Status Survey, 2014 OTÁP - Országos Táplálkozás és Tápláltsági Status Survey, 2014 OTÁP - Országos Táplálkozás és Tapplaltság
Állapot Vizsgálat, 2014 Permanent link to this document: https:// (2) NCD-RisC, National Adult BMI (ncdrisc.org/data-downloads-

Paquette MC. (2005): Perceptions of healthy eating: state of knowledge and research gaps, Canadian Journal of Public Health, Psouni S., Chasandra M., Theodorakis Y. (2016): Patterns of eating and Physical Activity Attitudes and Behaviors in Relation to Body link to this document: doi:10.4236/psych.2016.72020

Sabbe D., Bourdeaudhuij D., Legisest E., Maes L. (2008). A clusteranalytical approach towards physical activity and eating habits among 10-year-old children, Health Education Research, 23 (5): Sajtos L., Mitev A. (2007): SPSS kutatási és adatelemzési kézikönyv, Budapest: Alinea Kiadó, ISBN: 978-963-9659-08-7

Szonda Ipsos (2007): Az egészségstílus. Szegmentáció és barométer a hatékony egészségügyi kommunikáció támogatásához. http://www. matr.

Tanton J., Dodd L. J., Woodfield L., Mabhala M. (2015): Eatting behabiours of British University Students: A Cluster Analysis on a Neglected Issue. Advances in Preventive Medicine. 2015 Article dx.doi.org/10.1155/2015/639239

Törő́csik M. (2014): $\quad \mathrm{Az}$ ételfogyasztás $\begin{array}{r}\text { megatrend } \\ \text { kapsolo }\end{array}$ Permanent link to this document: http://taplalkozasmarketing. com/wp-content/uploads/02_T\%C3\%B6r\%C5\% 91csik-M.
Az-\% C $3 \%$ A 9 telfogyaszt\%C $3 \%$ A 1 s-megatrendA z-\% C 3\% A 9 t el f o g y a s z z t \%
kapcsol\% C3\%B3d\%C $3 \%$ Alsai.pdf

Trends of 2019 (2019. év trendjei): http://www.trendinspiracio.hu/

(a) In: Beckmann S. C. Ringberg T. Ritter, T., editors. The six senses. The Essentials of Marketing. 39th EMAC Conference : Copenhagen Business School. Department of Marketing, Denmark, 1-4 June 2010 Vries H., Riet J. Spigt M., Mestsem: 978 J 5 a kker M. Vermunt J. K., Kremers S. (2008): Clusters of lifestyle behaviors: Results from 
the Dutch SMILE study, Preventive Medicine, 46 (2): 203 - 208.

Permanent link to this document: doi: 10.1016/j.ypmed.2007.08.005

Wah C. S. (2016): Gender differences in eating behavior, International of Accounting \& Business Management, Vol. 4 Iss 2 pp. 116 - 121. Permanent link to this document: doi: $10.24924 /$ ijabm/2016.11/v4.iss2/116.121

WHO: Average BMI across WHO countries: http://www.who.int/ gho/ncd/risk_factors/overweight/en/ (Accessed 27 May 2019.) 